Revistade
Economild
Contemporâned

\title{
UM ESTUDO DA RIQUEZA FINANCEIRA DO BRASIL A PARTIR DA MATRIZ DE PATRIMÔNIO FINANCEIRO DO IBGE*
}

\author{
Antonio Carlos Macedo e Silva ${ }^{a}$ \\ Cláudio Hamilton Matos dos Santos ${ }^{b}$

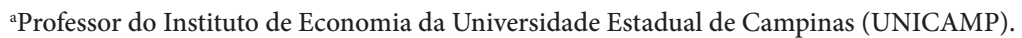

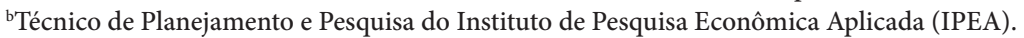

Artigo recebido em 28/10/2015 e aprovado em 04/08/2016.

RESUMO: Este texto procura extrair das contas financeiras (2005-2009), das contas de patrimônio (2004-2009) e da matriz de patrimônio financeiro (2009), publicadas pelo IBGE, um retrato tão preciso quanto possível do tamanho e da composição da riqueza financeira no Brasil. O texto inova ao calcular as posições financeiras intrassetoriais, bem como no próprio modo de apresentação da matriz de patrimônio. Outra contribuição consiste em cruzar os dados do IBGE com aqueles das Demonstrações Financeiras do Banco Central, o que permite, para alguns fins, desfazer o duvidoso agregado em que se confundem os números da autoridade monetária com aqueles das demais instituições financeiras.

PALAVRAS-CHAVE: Contabilidade social; fluxo de fundos; riqueza financeira.

CLASSIFICAÇÃO JEL: E16; E44.

\footnotetext{
* Os autores desejam agradecer a boa vontade e os esclarecimentos recebidos de Carlos Sobral (IBGE) e de Maurício Botelho Ribeiro (BCB), bem como as sugestões do parecerista anônimo da REC.

Correspondência para: Antonio Carlos Macedo e Silva.

Contato: macedo@eco.unicamp.br.
} 


\title{
FINANCIAL WEALTH IN BRAZIL: A STUDY BASED ON IBGE'S WHOM-TO-WHOM FINANCIAL BALANCE-SHEET MATRIX
}

\begin{abstract}
This paper aims to extract a picture as detailed as possible of the size and structure of the financial wealth in Brazil, using the financial accounts (2005-2009), the balance sheet accounts (2004-2009) and the balance sheet matrix for the year 2009. Two contributions made by this paper are the calculation of the intrasectoral financial positions, as well as the very presentation of the balance sheet matrix. Furthermore, based on the Brazilian Central Bank financial statements, the paper manages to unwind, for some purposes, the dubious aggregate in which the Monetary Authority figures are mixed with those of the other financial firms.
\end{abstract}

KEYWORDS: Social accounting matrix; flow of funds; financial wealth. 


\section{INTRODUÇÃO}

Este texto tem como objetivo extrair dos dados disponíveis um retrato (inicial e parcial) da riqueza financeira no Brasil, tema que permanece incógnito em seus aspectos mais básicos. Qual seu tamanho? Qual sua composição? Qual sua distribuição entre os setores institucionais? Como se distinguem os portfólios financeiros desses setores? De que forma está constituída a trama de ativos e passivos financeiros que conecta os agentes econômicos dentro de cada setor institucional e entre os setores?

Respostas iniciais e parciais a essas perguntas são propostas neste texto. Iniciais, de um lado, porque a publicação dos dados das contas financeiras e de patrimônio financeiro pelo IBGE e pelo Banco Central parece não ter repercutido, até aqui, na comunidade acadêmica. A breve apresentação dos dados feita pelo IBGE (2011) é, talvez, a única referência existente sobre o tema. Iniciais (e parciais), de outro, porque a base de dados divulgada é, a um tempo, volumosa e lacunar. Dado o tamanho da base, não é possível explorá-la toda em um único texto. Mas, dadas suas limitações, os resultados de quaisquer explorações são necessariamente parciais. Com efeito, as séries são cur$\operatorname{tas}^{1}$; a matriz de patrimônio financeiro só foi construída, até aqui, para o ano (atípico) de 2009. Além disso, os setores institucionais e os instrumentos financeiros são apresentados com grau de agregação elevado. Falta ainda uma informação crucial - o patrimônio não financeiro - o que impede o cálculo do patrimônio líquido dos setores institucionais e encurta o fôlego da interpretação.

O restante deste texto está dividido em quatro partes. A parte 2 apresenta os conceitos básicos sobre a mensuração da riqueza financeira no sistema de contas nacionais das Nações Unidas. A parte 3 trata das especificidades das contas nacionais brasileiras. Os números da riqueza financeira brasileira são apresentados e discutidos na parte 4; segue-se uma breve conclusão.

\section{A RIQUEZA FINANCEIRA NOS SISTEMAS DE CONTAS NACIONAIS}

Os dados do IBGE seguem os marcos conceituais do Sistema de Contas Nacionais publicado pelas Nações Unidas, dentre outros organismos multilaterais, em 2008 (SNA, 2008)².

1 Com base nas Contas Nacionais referência 2000, há seis anos de dados para o patrimônio financeiro (2004-2009) e cinco anos para os fluxos (2005-2009). A publicação das Contas Nacionais referência 2010 (IBGE, 2015) acrescentou o período 2010-2013.

2 Para simplificar, todas as edições do System of National Accounts são referidas pelo acrônimo SNA e não pelas instituições responsáveis (United Nations para a edição de 1968 e o pool de instituições, começando pela European Commission, no caso das edições de 1993 e 2008). 
Uma característica central do SNA 2008 - e de seu antecessor de 1993 (SNA, 1993) - é a utilização das chamadas contas econômicas integradas (CEI) que, por sua vez, são divididas em três conjuntos de contas (Quadro 1).

As "contas correntes" - o primeiro conjunto - "registram a produção de bens e serviços, a criação de rendimentos através da produção, a subsequente distribuição e redistribuição dos rendimentos pelas unidades institucionais e a utilização dos rendimentos em consumo e poupança" (IBGE, 2011, p. 7).

\section{Quadro 1 - Estrutura das contas integradas}

\begin{tabular}{|l|c|c|}
\hline Conta & Saldo & Principais agregados \\
\hline Contas correntes & Valor adicionado & \\
\hline Conta de produção & & PIB \\
\hline Distribuição e uso da renda & & \\
\hline Distribuição primária & Excedente operacional/renda mista & \\
\hline Geração da renda & Saldo das rendas primárias & Renda nacional \\
\hline Alocação da renda primária & Renda disponível & nacional \\
\hline Distribuição secundária da renda & & Poupança nacional \\
\hline Uso da renda & & \\
\hline Contas de acumulação & & \\
\hline Conta de capital & Capacidade/necessidade líquida de financiamento & \\
\hline Conta financeira & & Riqueza nacional \\
\hline Outras variações nas contas de ativos & Variações no patrimônio líquido respectivas & \\
\hline Variações no volume & & \\
\hline Conta de revalorização & Patrimônio líquido & \\
\hline $\begin{array}{l}\text { Conta de patrimônionio líquido } \\
\text { não financeiro) }\end{array}$ & & \\
\hline No início do ano & Variações no patrimônio líquido & \\
\hline Variações em ativos e passivos & & \\
\hline No final do ano & & \\
\hline
\end{tabular}

Fonte: SNA (2008).

O segundo grupo, em que estão as contas de acumulação, explicita o que ocorre com os fluxos de poupança estimados a partir das contas correntes. A poupança entra na conta (de acumulação) de capital como um "recurso", juntamente com as transferências líquidas de capital recebidas. Ambas determinam variações equivalentes no patrimônio líquido dos setores (sujeito, ainda, às "outras variações” nas contas de ativos, referidas adiante). No lado dos usos, aparece a formação de capital, que, em essência, esgota-se em ativos produzidos: ativos fixos (incluindo edifícios e outras estruturas) e estoques (além de valores, como metais e pedras preciosas) ${ }^{3}$.

3 Mas há também os investimentos em ativos não financeiros não produzidos, como transações que dizem respeito a recursos naturais, goodwill e ativos de marketing. 
Aqui se introduz o conceito crucial para a integração das operações financeiras às contas nacionais: o saldo financeiro líquido (ou acumulação líquida de ativos financeiros), que corresponde ao excesso da poupança de cada setor sobre seu dispêndio em investimento. Na terminologia do SNA 2008, há net financial borrowing quando a poupança é inferior ao investimento e net financial lending no caso oposto. Na terminologia do IBGE (2011), fala-se em, respectivamente, necessidade ou capacidade líquidas de financiamento. Quando, por exemplo, o investimento das empresas não financeiras supera os lucros retidos, a necessidade líquida de financiamento não precisa ser atendida literalmente pela tomada de empréstimos (lending), podendo as empresas recorrer tanto à emissão de ações quanto à venda de ativos.

Considerando apenas quatro setores institucionais (famílias, empresas privadas, governo e setor externo), resulta a identidade contábil ${ }^{4}$ :

$$
\left(S_{F}-I_{F}\right)+\left(S_{E}-I_{E}\right)+\left(S_{G}-I_{G}\right)+(M-X) \equiv S F_{F}+S F_{E}+S F_{G}-S T C \equiv 0,
$$

em que $(M-X)$ é o oposto do saldo em transações conta correntes (STC) da economia nacional ("poupança externa").

A soma dos saldos financeiros líquidos $(S F)$ das famílias $(F)$, das empresas $(E)(F)$, do governo $(G)$ e do resto do mundo é necessariamente igual a zero: a um setor institucional deficitário (e emissor de passivos financeiros) necessariamente corresponde um setor superavitário (e comprador de ativos financeiros).

Setores sistematicamente superavitários ou deficitários tendem a se tornar, respectivamente, "credores" ou "devedores" líquidos, o que poderá ter implicações sobre arobustez (ou fragilidade) financeira de seus portfólios (MINSKY, 1982). Mas a análise dessas implicações requer cautela. "Crédito" e "dívida" são aqui entendidos sem sentido lato. A diferença entre os totais de ativos financeiros e passivos financeiros(inclusive ações), como definidos no SNA(2008), é o "patrimônio líquido financeiro" (SNA, 2008, p. 454; LEQUILLER e BLADE, 2006, p. 211). Saldos financeiros acarretam (se desconsiderados ganhos/perdas de capital $)^{5}$ variações idênticas no patrimônio líquido financeiro (doravante PLF).

\footnotetext{
4 Posta em voga, aliás, pela crise financeira de 2007-2008, a partir de trabalhos de Wynne Godley (por exemplo, 1999).

5 Neste texto, a expressão ganhos/perdas de capital equivale às "outras variações nas contas de ativos", que resultam da soma de dois itens do SNA: revalorizações e outras variações de volume (ver abaixo).
} 
O patrimônio líquido stricto sensu (doravante patrimônio líquido), porém, inclui os ativos não financeiros; ademais, seu cálculo deduz do valor dos ativos totais somente o capital de terceiros (passivos exigíveis). Neste, estão contidos os empréstimos, mas não as contribuições que engrossam o capital próprio (ações, cotadas ou não, e outras participações) e que representam (ao menos em parte) direitos não resgatáveis sobre o capital da empresa e cuja remuneração não é estabelecida na forma de um contrato de dívida (ver Quadro 2) ${ }^{6}$.

Considere-se uma família cujo investimento residencial positivo é equivalente à sua poupança. O PLF permanece constante, ao passo que o patrimônio líquido aumenta (sempre abstraindo a possibilidade de ganhos/perdas de capital) no valor da poupança. Já um excesso de investimento sobre poupança reduz pro tanto seu PLF. Tal como antes, a poupança, se positiva, aumenta por tanto o patrimônio líquido, sendo o excesso de investimento sobre poupança compensado pelo aumento do passivo financeiro. $\mathrm{O}$ efeito sobre a fragilidade financeira, se aferida pela alavancagem, medida pela razão entre ativos totais (ou, alternativamente, capital de terceiros) e patrimônio líquido (capital próprio), não pode ser determinado a priori, pois depende das taxas de crescimento do numerador e do denominador utilizados.

\section{Quadro 2 - Patrimônio líquido e patrimônio líquido financeiro}

\begin{tabular}{|l|l|}
\hline Ativo & Passivo \\
\hline A. Ativos financeiros & C. Passivo exigível (títulos, empréstimos, outros débitos) \\
\hline B. Ativos não financeiros & D. Patrimônio líquido \\
\hline & d1. Ações e outras participações \\
\hline & d2. Patrimônio líquido financeiro \\
\hline & d3. Resíduo \\
\hline $\begin{array}{l}\text { Patrimônio líquido propriamente dito: } A+B-C=D \\
\text { Patrimônio líquido financeiro: } A-(C+d 1)=d 2\end{array}$ & \\
\hline
\end{tabular}

Fonte: Elaboração própria.

Considere-se agora uma firma. Excessos de investimento sobre poupança, se financiados pela emissão de ações (ou por outras participações de capital), embora reduzam o PLF, aumentam pro tanto o patrimônio líquido. O aumento total deste é equi-

6 Na análise de situações concretas, é conveniente levar em consideração a existência de ações preferenciais (que podem ser resgatáveis) e a prioridade concedida ao share holder value, que talvez contribuam para reduzir, em algum grau, as diferenças entre passivos exigíveis e não exigíveis (ao mesmo tempo em que a chamada financeirização parece implicar também a redução da emissão líquida de ações como mecanismo de financiamento das empresas). Ver, por exemplo, Epstein (2005). 
valente à soma de lucros retidos (vale dizer, poupança da firma), emissão de ações e injeções de capital na forma de outras participações.

Voltemos à descrição das contas integradas. Os saldos financeiros líquidos são transportados para a conta financeira como recursos. Representam a proverbial ponta do iceberg. Apenas significam que, no caso de (por exemplo) capacidade líquida de financiamento, terá havido, na comparação entre dois pontos no tempo, um acréscimo líquido no total de ativos financeiros (ou um decréscimo nos passivos). A informação, embora relevante, é parcial.

Após o registro do saldo financeiro líquido, a conta financeira descreve circunstanciadamente a "aquisição" (i.e., emissão) líquida dos vários tipos de passivos, contraposta, nas colunas dedicadas aos usos, às aquisições líquidas dos vários tipos de ativos. Um setor no qual poupança e investimento tenham se igualado pode ter realizado, no mesmo período, diversificadas e volumosas transações de natureza financeira. Pode ter emitido passivos financeiros para adquirir ativos financeiros adicionais ou para substituir outros passivos; pode ter liquidado ativos, trocando-os por outros ou redimindo passivos. Portanto, mesmo na ausência de saldos financeiros líquidos, outras operações financeiras podem alterar substancialmente a composição do portfólio.

Ademais, a descrição circunstanciada das operações financeiras líquidas de um setor não é, de forma alguma, uma proxy da totalidade de suas operações financeiras em um período. Um setor pode ter realizado numerosas operações de aquisição e venda de ações; se equivalentes, a aquisição líquida dessa categoria de ativo será nula (ainda que a composição do portfólio de ações possa ter mudado de forma significativa); da mesma forma, um setor pode terminar o ano sem alterações no valor dos empréstimos contraídos, tendo tomado (e honrado) múltiplos empréstimos de curto prazo.

De fato, os fluxos líquidos que constam da conta financeira são obtidos por resíduo. Se, do ponto de vista lógico, parece apropriado apresentar as contas financeiras antes das contas de patrimônio, do ponto de vista prático, a construção das contas segue o caminho oposto. A informação que os serviços estatísticos podem coletar é a que provém dos balanços dos setores, no início e no final do período. Feito isso, estimam-se os ganhos e perdas de capital. Assim, torna-se possível calcular:

Fluxos líquidos = Estoque final - Estoque inicial - ganhos (perdas) de capital.

Somando-se os fluxos líquidos para todos os instrumentos financeiros, obtém-se, é claro, o valor da capacidade/necessidade de financiamento.

Completando as contas de acumulação, as "outras variações" discriminam, na conta "variações no volume", as alterações devidas a fatores como catástrofes naturais, descobertas de jazidas, desapropriações, denúncias de contratos etc. e, "na conta de 
revalorização", ganhos e perdas de capitais devido a variações nominais no valor dos instrumentos (inclusive as resultantes de mudanças na taxa de câmbio).

É conveniente deixar claro que, na confecção da conta financeira, são agregadas as operações financeiras realizadas entre um setor e todos os demais. Os dados finais mostrarão, por exemplo, que as famílias adquiriram, ao longo do ano contábil, liquidamente, certo valor em ações. Não será possível distinguir, porém, as compras de ações das empresas financeiras daquelas de empresas não financeiras. Para tal, é necessário elaborar uma tabela (ou mais precisamente uma matriz) dita whom-to-whom.

Resta dizer uma última palavra sobre a definição e a classificação dos ativos e passivos financeiros. Em uma definição estrita, um passivo financeiro é um contrato emitido quando um agente necessita mobilizar (em geral por um período finito e sob condições de remuneração estabelecidas de forma precisa) recursos de terceiros, para os quais, obviamente, a obrigação contraída pelo devedor representa um ativo. A definição do SNA, mais ampla, inclui, além das ações, um ativo para o qual essa contrapartida inexiste: o ouro monetário, propriedade das autoridades monetárias.

Os ativos financeiros são classificados pelo SNA em categorias que refletem, grosso modo, uma liquidez decrescente: ouro monetário e direitos especiais de saque; moeda e depósitos (inclusive posições interbancárias, depósitos de poupança e a prazo fixo, bem como operações compromissadas, quando relativas a passivos de instituições recebedoras de depósitos e incluídas nas medidas nacionais dos agregados monetários); títulos de dívida; empréstimos (não negociáveis, com possível reclassificação como títulos dos empréstimos que se tornam negociáveis); ações e quotas em fundos de investimento (divididos em money market funds e outros fundos); seguros e direitos previdenciários; derivativos financeiros; outras contas a receber/pagar (ver SNA, 2008, cap. 11) ${ }^{7}$.

\section{AS CONTAS INTEGRADAS E AS CONTAS FINANCEIRAS NO BRASIL}

Particularmente (mas não só) no caso de países em desenvolvimento, a adoção dos procedimentos contábeis recomendados pelas instituições multilaterais é feita de modo paulatino. O Brasil não é uma exceção. A “espinha dorsal” das contas nacionais - as contas integradas - é, no nosso caso, uma obra inacabada e assim continuará no

\footnotetext{
Segundo o SNA (2009, p. 382), este item contém, em essência, "accrual adjustments" (ajustes pelo regime contábil de competência). Registra, de um lado, operações de crédito comercial, quando "bens e serviços foram entregues mas o pagamento não foi ainda recebido" e adiantamentos ("advances") relativos ao pagamento de bens em processamento ("work-in-progress"). O item inclui, também, o valor de impostos, dividendos, aluguéis, salários e contribuições sociais a pagar ou receber (SNA, 2008, p. 68).
} 
futuro previsível. Isso diz respeito, em primeiro lugar, à ausência de partes; em segundo lugar, ao grau de agregação das partes já existentes.

A partir de 2003, as contas nacionais trimestrais passaram a incluir os números da conta financeira consolidada, contendo as variações de ativos e passivos da economia como um todo (FEIJÓ et al., 2013, p. 228). Somente em 2011, porém, uma iniciativa conjunta do IBGE e do Banco Central (IBGE, 2011) daria à luz as contas financeiras anuais e as contas de patrimônio dos setores institucionais, relativas ao período 2004-2009, como parte das Contas Nacionais referência 2000. O conjunto de planilhas incluiu, ainda, a matriz de patrimônio financeiro de 2009 - por sinal, a única divulgada até a finalização deste texto ${ }^{8}$. Em 2015, já com base nas Contas Nacionais referência 2010, as séries da conta financeira passaram a cobrir os anos 2010-2013. O lado negativo dos aprimoramentos metodológicos introduzidos (ver adiante) foi, como de hábito, a descontinuidade das séries. Somente os números finais da conta de patrimônio de 2009 (que obviamente correspondem aos valores iniciais da conta de patrimônio de 2010) foram objeto de retropolação, que introduziu diferenças significativas em relação aos números anteriormente divulgados. A matriz de patrimônio financeiro de 2009, porém, não foi revista. Dada a ênfase deste texto na matriz, os comentários subsequentes concentram-se no período 2004-2009, com base, portanto, nas Contas Nacionais referência 2000 .

A divulgação da Conta Financeira concluiu, de certa forma, a conta de acumulação, ao passo que a divulgação da Conta de Patrimônio Financeiro apenas deu início à construção da Conta de Patrimônio. Convém explicar as qualificações.

Em primeiro lugar, o grau de agregação, no que tange aos setores institucionais, é ainda um pouco superior ao máximo recomendado pelo $\mathrm{SCN}^{9}$ : nas contas financeiras $^{10}$, estão agregadas as famílias e as instituições privadas sem fins de lucro a serviço das famílias (ISFLSF). Em segundo lugar, persiste uma ausência notável: a da conta de patrimônio não financeiro, referida como um objetivo de médio prazo, com cronograma ainda indefinido (IBGE, 2013a, p. 6).

8 Novas matrizes de patrimônio financeiro, sob a responsabilidade do BACEN, deveriam vir a público em 2016.

9 A desagregação básica recomendada pelo SNA divide a economia em cinco setores: empresas financeiras e não financeiras, famílias, governo e instituições privadas sem fins de lucro a serviço das famílias. Desagregações ulteriores são não só possíveis, como recomendáveis (podendo discriminar subsetores ou indústrias).

${ }^{10}$ As Contas Econômicas Integradas brasileiras separam famílias e ISFLSF somente até o cálculo da capacidade/necessidade financeira líquida. 
Certamente mais relevante ${ }^{11}$ do que a agregação de famílias e ISFLSF é a agregação de todas as empresas financeiras, inclusive o Banco Central, que, no entanto, opera segundo uma lógica inteiramente particular ${ }^{12}$. Combinando os dados do IBGE aos das Demonstrações Financeiras do Banco Central foi possível estimar neste texto, em alguns casos, os números relativos às empresas financeiras exclusive o $\mathrm{BCB}$.

A construção das bases de dados (ou mesmo a adequação das bases existentes aos critérios do SCN) não é operação trivial. Basta ter em conta o caso dos Estados Unidos, onde o FED já produz, há décadas, estatísticas consideravelmente desagregadas. A despeito disso, as contas integradas do país são ainda apresentadas, no que se refere às empresas financeiras,com agregação semelhante à nossa. Segundo Cagetti et al. (no prelo), o próximo passo consistirá em explicitar três subsetores: Banco Central, seguradoras e fundos de pensão, e outras empresas financeiras ${ }^{13}$.

A indisponibilidade de dados sobre o patrimônio não financeiro dos setores institucionais significa que não é possível calcular o patrimônio líquido - bem como uma série de indicadores pertinentes ao estudo da liquidez e da alavancagem - dos setores institucionais ${ }^{14}$.

A classificação brasileira dos ativos financeiros (Quadro 3) segue de perto a sugerida pelo SNA e, de fato, avança para além das categorias básicas, oferecendo alguma desagregação adicional, no caso das contas financeiras e da matriz de patrimônio financeiro ${ }^{15}$. Algumas observações: os "outros depósitos" compreendem as contas de

${ }^{11}$ O famoso boletim Z1 (Financial Accounts of the United States, antes conhecido como Flow of Funds Accounts of the United States) também consolida, na maior parte de suas tabelas, as famílias e as ISFLSF. As Integrated Macroeconomic Accounts (IMA, desenvolvidas em 2006) fazem o mesmo, além de separarem as empresas não financeiras em corporate e non-corporate, de um lado, e o governo em federal, de um lado, e estaduais e locais, de outro (YAMASHITA, 2013).

12 A "segunda rodada" de desagregação sugerida pelo SNA separa as empresas financeiras em nove subsetores (entre os quais o Banco Central), "de acordo com sua atividade e a liquidez de seus passivos" (SNA, 2008, p. 75).

${ }^{13}$ Yamashita (2013, p. 26) sublinha o interesse de proceder, posteriormente, a uma desagregação adicional: "Separating other financial institutions from depository institutions would advance our understanding of distinct roles that different financial institutions may play over the business cycle".

14 Mais uma breve referência às contas norte-americanas que pode ser ilustrativa. Em nenhum dos seis setores, o valor da terra é tomado em conta (WASSHAUSEN, 2011); em três setores (empresas financeiras, governo federal e governos subnacionais), não há dados julgados confiáveis para o valor dos imóveis (sendo utilizado, então, o valor das estruturas, juntamente com o valor de equipamentos e softwares). O mesmo autor ressalta a importância dos ativos não financeiros: tanto para as famílias quanto para as corporações não financeiras, as flutuações no patrimônio líquido, de 2000 a 2009, responderam muito mais a variações na conta de revalorização, refletindo variações nos preços dos imóveis, do que a variações na formação bruta de capital fixo.

15 No pacote de informações publicado em 2011, com base nas Contas Nacionais referência 2000, a discriminação variava conforme a peça (conta financeira, de patrimônio ou matriz). As rubricas do Quadro 3 correspondem à apresentação das contas financeiras no período 2005-2009. A matriz, por seu turno, 
poupança e os depósitos a prazo; títulos e empréstimos são de curto prazo quando sua maturidade é inferior ou igual a um ano; as "outras participações" incluem as quotas em todos os tipos de fundos de investimento; em outros débitos/créditos, a rubrica "outros" é empregada para forçar o fechamento das contas acima e abaixo da linha, eliminando a eventual discrepância estatística ${ }^{16}$.

\section{Quadro 3 - Ativos financeiros discriminados nas contas financeiras brasileiras referência 2000}

\begin{tabular}{|l|c|}
\hline Ouro e DES & Ações e outras participações \\
Numerário e depósitos & Ações cotadas \\
Numerário & Participações em fundos de investimento \\
Depósito transferível & Reservas técnicas de seguros \\
Outros depósitos & Reservas de seguros de vida e de fundos de pensão \\
Títulos, exceto ações & Reservas para prêmios e sinistros \\
Curto prazo & Outros débitos/créditos \\
Longo prazo & Créditos comerciais e adiantamentos \\
Derivativos financeiros & Outros \\
Empréstimos & \\
Curto prazo & \\
Longo prazo & \\
\hline
\end{tabular}

Fonte: IBGE (2011).

É importante sublinhar a diferença entre os conceitos de agregação e consolidação. Tanto nas Contas Financeiras quanto nas de Patrimônio, quando referentes a setores institucionais (mas não à economia como um todo), os números são agregados (pois somam os valores referentes às unidades institucionais cobertas) mas não consolidados: por exemplo, o valor das ações de propriedade das empresas não financeiras inclui suas aplicações em ações emitidas por empresas financeiras, pelo resto do mundo $e$ pelas próprias empresas não financeiras. A consolidação eliminaria, no cômputo dos

agrega todos os números relativos à rubrica reservas técnicas de seguros, mas discrimina títulos em moeda nacional e estrangeira, bem como empréstimos de curto e longo prazos. Essas informações não estavam disponíveis nas contas de patrimônio, que, ademais, omitia qualquer desagregação das rubricas numerário e depósitos, títulos, exceto ações, empréstimos, ações e outras participações, reservas técnicas de seguros e outros débitos/créditos. Nas Contas Nacionais referência 2010, a desagregação das contas financeiras foi estendida às contas de patrimônio; em ambas, o item Reservas técnicas de seguros passou a se denominar Planos de seguros, de previdência e regime de garantias padronizadas, estando agora desagregado em três rubricas: Reservas técnicas de seguros não vida, direitos de seguros de vida e rendas vitalícias e direitos sobre fundos de pensão (IBGE, 2015).

${ }_{16}$ Segundo o SNA (2008, p. 396), cabe às instituições estatísticas decidir se publicam a discrepância ou a alocam nos itens que, em sua opinião, contêm estimativas menos acuradas. 
valores agregados para cada setor institucional, ativos que correspondam a passivos emitidos por unidades do próprio setor.

A matriz de patrimônio financeiro, por fim, tem por objetivo explicitar as relações financeiras entre os setores institucionais. Apresenta, portanto, os dados consolidados de cada um dos setores. Assim, por exemplo, o valor do passivo em ações das empresas não financeiras que consta da matriz corresponde apenas ao valor das ações de empresas não financeiras detidas pelos demais setores institucionais (empresas financeiras, governo, famílias e resto do mundo). Como veremos no próximo item, a comparação entre os números da matriz e os números da conta financeira do mesmo ano permitem reverter a consolidação e explicitar tanto as posições intersetoriais quanto as intrassetoriais.

\section{O QUE DIZEM AS CONTAS INTEGRADAS SOBRE A RIQUEZA FINANCEIRA NO BRASIL?}

O item 4.1 apresenta alguns dos fatos básicos relativos aos fluxos e estoques financeiros no Brasil. O item 4.2 passa à análise da matriz de patrimônio financeiro de 2009 , que permite descrever de forma detalhada os portfólios de cada setor e suas relações patrimoniais com os demais.

\subsection{FLUXOS E ESTOQUES FINANCEIROS: UMA PRIMEIRA APROXIMAÇÃO}

$\mathrm{Na}$ análise das contas financeiras, um ponto de partida natural é a série de saldos financeiros (capacidades/necessidades líquidas de financiamento) ${ }^{17}$. O Gráfico 1 mostra os saldos normalizados pelo PIB (ref. 2000) anual ${ }^{18}$.

\footnotetext{
${ }^{17}$ Com base nas Contas Nacionais referência 2000, a série está disponível para o período 2000-2009. Antes de 2003, porém, a contabilidade do BCB não possibilita o cálculo do resultado líquido com juros, crucial para a estimativa de seu saldo financeiro. Este foi calculado da seguinte forma: deduzimos do "resultado líquido com juros em moeda local e moedas estrangeiras" as rubricas pessoal, fabricação e distribuição de numerário, outras despesas administrativas e outras (dados das Demonstrações Financeiras da instituição). O procedimento, desenvolvido a partir de informações obtidas junto ao IBGE, gera um valor completamente diferente dos resultados dos exercícios, como calculados pelo BCB. A diferença, particularmente grande de 2003 a 2007, deve-se, fundamentalmente, ao fato de que as normas contábeis da instituição transportam diretamente para os resultados os ganhos e perdas associados às reservas oficiais, enquanto os procedimentos do IBGE separam claramente fluxos e revalorizações. Em 2008, novos procedimentos instituíram a chamada "conta de equalização cambial", introduzindo um ajuste de contas entre o Tesouro e o BCB que precede o cálculo do resultado do exercício.

${ }^{18}$ Os autores disponibilizarão os valores em reais correntes para todos os interessados.
} 
O quadro brasileiro reproduz, até certo ponto, alguns fatos estilizados observados em outras economias (BARBOSA FILHO et al., 2006). O conjunto famílias-ISFLSF é ordinariamente superavitário, realizando acumulação líquida de ativos financeiros; o governo é sistematicamente deficitário; as empresas não financeiras oscilam entre o vermelho e o negro ${ }^{19}$; as empresas financeiras tendem a ser superavitárias.

No curto período para o qual esses dados estão disponíveis, três fatos chamam a atenção:

a. Durante os três primeiros anos de retomada do crescimento após a crise de 2003, o saldo financeiro das empresas não financeiras manteve-se em território positivo, somente em 2007 assumindo o comportamento normal (ao menos na economia norte-americana) em períodos de expansão (saldo negativo). Grosso modo, porém, é possível afirmar que os números acompanham a série de formação bruta de capital fixo do setor como razão do PIB: a queda desta última, entre 2001 e 2003, coincide com o aumento do saldo; sua recuperação, mais marcada em 2007 e 2008, coincide com a redução do saldo.

b. Ainda mais do que a persistência, o tamanho do saldo financeiro positivo das empresas financeiras (3,3\% do PIB, na média do período).

c. A correlação negativa entre os saldos da administração pública e das empresas financeiras. Obviamente, o resultado expressa o papel das empresas financeiras como custodiantes e detentoras finais da dívida pública mobiliária federal interna (DPMFI). As instituições financeiras são as principais responsáveis pela custódia dos títulos; auferem, em primeira mão, os retornos correspondentes, para depois transferi-los aos detentores finais. Do ponto de vista da custódia, as instituições financeiras respondiam por algo como 85,5\% da DPMFI em poder do público, em dezembro de $2008^{20}$. Nesse mesmo mês, segundo Bittencourt (2009), as categorias pessoa jurídica financeira e investidores institucionais ${ }^{21}$ eram as detentoras finais de $76,6 \%$ da DPMFI em poder

${ }^{19}$ Nos Estados Unidos, este é o caso das corporações não financeiras, enquanto as demais firmas não financeiras são sistematicamente deficitárias.

20 Segundo o Relatório Mensal da Dívida Pública Federal, de dezembro de 2008, a porcentagem resulta da soma de títulos detidos em carteira própria (dos bancos, i.e., tesouraria), "títulos vinculados" e "contas Cliente Especial dos fundos de investimento regidos pela Instrução CVM".

${ }^{21}$ A primeira categoria inclui: “i) os recursos das tesourarias; ii) os valores detidos por pessoa jurídica financeira que não tem conta individualizada no Selic; e iii) instituições financeiras detentoras de fundos de investimento". Na segunda, entram, entre outros, os "fundos de investimentos dos segmentos previdência complementar (...), seguradora, sociedade capitalização", além "dos recursos administrados por entidades de previdência complementar, seguradoras (inclusive de saúde) e sociedade de capitalização" (BITTENCOURT, 2009, p. 390). 
do público. Não se deve esquecer, porém, que a DPMFI em poder do Banco Central (incluído entre as empresas financeiras) era então de $28,1 \%$ do total.

Esses padrões, precariamente estabelecidos a partir de uma série tão curta, refletem-se (com os ganhos/perdas de capital) nos números relativos ao patrimônio líquido financeiro, extraídos (com a exceção dos números do Banco Central, provenientes de suas Demonstrações Financeiras) das contas de patrimônio (e, portanto, não consolidados), disponíveis (com base na referência 2000) para o período 2004-2009. Evidentemente, quando se trata exclusivamente de ativos e passivos financeiros, a posição positiva de uns é necessariamente equivalente à posição negativa de outros. A soma é zero. A Tabela 1 mostra o PLF de cada setor, normalizado pelo PIB corrente. Fica claro que os setores famílias - ISFLSF e resto do mundo dividem o papel de credores líquidos; na média do período, detiveram, respectivamente, $39,4 \%$ e 33,3\% do PLF. Em ordem decrescente, os maiores devedores líquidos foram as empresas não financeiras (-50,2\% do PIB no período), as financeiras $(-12,2 \%)$ e a administração pública $(-10,7 \%)^{22}$.

Tabela 1 - Setores institucionais: patrimônio líquido financeiro (\% do PIB)

\begin{tabular}{lcrrrrr}
\hline & $\mathbf{2 0 0 4}$ & $\mathbf{2 0 0 5}$ & $\mathbf{2 0 0 6}$ & $\mathbf{2 0 0 7}$ & $\mathbf{2 0 0 8}$ & $\mathbf{2 0 0 9}$ \\
\hline Empresas não financeiras & $-59,7$ & $-53,5$ & $-51,2$ & $-55,4$ & $-39,6$ & $-42,0$ \\
Empresas financeiras & $-16,5$ & $-17,0$ & $-16,0$ & $-15,3$ & 1,3 & $-9,6$ \\
Banco Central & 0,5 & 0,4 & 0,3 & 0,0 & 0,4 & 0,6 \\
Administração pública & $-7,8$ & $-5,7$ & $-7,6$ & $-8,6$ & $-16,6$ & $-17,5$ \\
Famílias e ISFLSF & 42,6 & 41,2 & 41,1 & 43,1 & 32,6 & 35,9 \\
Resto do mundo & 41,0 & 34,7 & 33,4 & 36,2 & 22,0 & 32,6 \\
Soma & 0 & 0 & 0 & 0 & 0 & 0 \\
\hline
\end{tabular}

Fonte: Elaboração própria com base em IBGE (Contas Nacionais).

Concorrem para a posição internacional de investimento negativa do país, em primeiro lugar, a posição líquida negativa em ações e outras participações (61\% dos passivos externos, na média do período 2005-2009; ver a Tabela 5), refletindo o estoque de investimento direto externo; em segundo lugar, os empréstimos (13,3\% dos passivos externos), que mais do que compensam o status de credor líquido em títulos, exceto ações (38,6\% dos ativos externos) e numerário e depósitos (12,2\% dos ativos externos $)^{23}$.

22 As dramáticas modificações observadas em 2008 (merecedoras de um artigo à parte) refletem, em larga medida, mudanças nas contas de revalorização dos vários setores, fundamentalmente nas rubricas ações e outras participações e títulos, exceto ações (refletindo, nesse caso, o aumento no valor da posição externa líquida do Banco Central).

${ }^{23}$ Ressalte-se que, embora a posição líquida em ações e outras participações seja negativa, o instrumento representou, na média do período, $35,8 \%$ dos nossos ativos externos. 


\section{Gráfico 1 - Saldos financeiros por setor institucional (\% do PIB)}

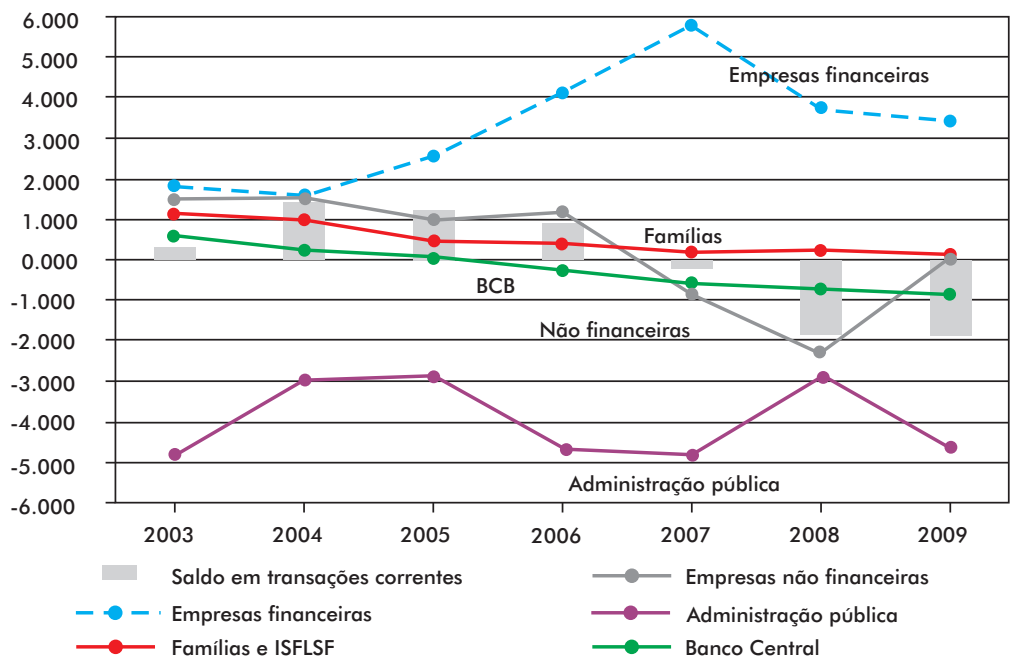

Fonte: Elaboração própria com base em IBGE (Contas Nacionais).

Para compreender as posições negativas dos setores empresariais, é essencial ter em mente as diferenças (acima mencionadas) entre o PLF e o patrimônio líquido. O cálculo do primeiro exclui, por definição, os ativos não financeiros, cujo valor é parte do segundo. Ora, os ativos não financeiros são particularmente importantes no portfólio das empresas não financeiras. É esperado - ou mesmo desejável - que tenham um PLF negativo. Para obter o patrimônio líquido stricto sensu seria preciso, ainda, deduzir, na coluna das fontes, o valor das ações e outras participações do total de passivos. Nesse segundo aspecto, decerto importante para as empresas financeiras, reside, possivelmente, a maior parte da explicação do patrimônio líquido financeiro negativo das empresas financeiras, para as quais o estoque de ativos não financeiros tem peso reduzido.

Nesse nível de agregação, porém, fluxos e estoques financeiros fornecem apenas uma primeira intuição acerca da natureza dos portfólios financeiros de cada setor e das interações entre eles. Os dados disponíveis oferecem três opções para o aprofundamento da análise.

Se o objetivo consiste em acompanhar o comportamento financeiro de cada setor institucional, o maior grau de detalhe, como explicado anteriormente, é (para o período 2005-2009) aquele possibilitado pelas contas financeiras. As aquisições líquidas de ativos e passivos variam significativamente de ano a ano, ao sabor das variações da conjuntura.

As contas de patrimônio podem ser usadas para o mesmo propósito. Isso porque elas não se limitam a apresentar os estoques (menos variáveis do que os fluxos) de ativos e passivos no final de cada ano: as variações dos estoques são decompostas (em- 
bora com menor grau de detalhe do que nas contas financeiras) em transações (fluxos) $e$ em outras variações (revalorizações e outras variações de volume). A inclusão dos ganhos e perdas de capital agrega uma informação importante para a compreensão dos fenômenos econômicos ocorridos em cada ano.

Entretanto, a derradeira opção, baseada na matriz de patrimônio financeiro de 2009, é a única que descreve de forma completa as relações - whom-to-whom - entre os setores institucionais. Ademais, o confronto dos dados da matriz com os da conta de patrimônio do mesmo ano permite o cálculo das (volumosas, como se verá) operações financeiras intrassetoriais (explicitando os componentes dos dados não consolidados). Por essas razões, foi esta a opção adotada neste texto.

\subsection{A MATRIZ DE PATRIMÔNIO FINANCEIRO}

Os dados da matriz de patrimônio serão explorados de diferentes pontos de vista. No item 4.2.1, a análise é feita do ponto de vista dos instrumentos. Os objetivos são evidenciar:

a. As participações (como credor e/ou devedor) de cada setor institucional no mercado do instrumento (Tabela 2);

b. O peso relativo de cada instrumento na riqueza financeira total (Tabela 3);

c. A composição dos setores financiadores para cada par setor institucional/instrumento (como, por exemplo, para títulos da dívida pública; Tabela 4).

No item 4.2.2, adota-se o ponto de vista dos setores institucionais. Tanto as matrizes teóricas quanto as matrizes whom-to-whom dos serviços estatísticos nacionais abstraem, por construção, as relações patrimoniais de natureza intrassetorial. Felizmente, porém, o uso conjugado da conta de patrimônio e da matriz de 2009 permite o cálculo das posições intrassetoriais.

\subsubsection{A ÓTICA DOS INSTRUMENTOS E DOS MERCADOS}

A Tabela 2 - construída com base na matriz de patrimônio original - é o equivalente possível, para a economia brasileira, das matrizes de estoques dos modelos stock-flow consistent (SFC) ${ }^{24}$. A apresentação tem por objetivo facilitar (como nos modelos) a

\footnotetext{
${ }^{24}$ A metodologia, desenvolvida (nos marcos do "velho keynesianismo") por James Tobin e seus colaboradores, foi depois apropriada por economistas pós-keynesianos como Wynne Godley e Marc Lavoie.
} 
visualização dos portfólios de cada setor. Em um modelo teórico haveria pelo menos um ativo "real": o estoque de capital fixo. A matriz brasileira, embora não inclua ativos reais, mostra uma trama de relações financeiras bem mais intrincada do que aquela que os modelos ousam analisar.

Tabela 2 - Matriz de patrimônio financeiro de 2009 - distribuição entre os setores de cada instrumento financeiro (\%)

\begin{tabular}{|c|c|c|c|c|c|c|c|c|c|c|c|}
\hline & \multicolumn{2}{|c|}{ 1. Financeiras } & \multicolumn{2}{|c|}{$\begin{array}{c}2 . \\
\text { Administração } \\
\text { Pública }\end{array}$} & \multicolumn{2}{|c|}{$\begin{array}{l}\text { 3. Não- } \\
\text { financeiras }\end{array}$} & \multicolumn{2}{|c|}{$\begin{array}{l}\text { 4. Famílias e } \\
\text { ISFLSF }\end{array}$} & \multicolumn{2}{|c|}{$\begin{array}{l}\text { 5. Resto do } \\
\text { mundo }\end{array}$} & \multirow[t]{2}{*}{ 6. Tota } \\
\hline & $\mathbf{A}$ & $\mathbf{P}$ & A & $\mathbf{P}$ & $\mathbf{A}$ & $\mathbf{P}$ & $\mathbf{A}$ & $\mathbf{P}$ & A & $\mathbf{P}$ & \\
\hline 1. Ouro Monetário e DES & 100,00 & & & & & & & & & $-100,00$ & 0 \\
\hline \multirow[t]{2}{*}{ 2. Numerário e Depósitos } & 1,96 & & & & & & & & & $-1,96$ & \\
\hline & & $-98,04$ & 48,46 & & 23,28 & & 25,78 & & 0,52 & & 0 \\
\hline \multirow[t]{4}{*}{ 3. Títulos, exceto ações } & & $-15,23$ & & & 6,78 & & 6,08 & & 2,37 & & 0 \\
\hline & 59,87 & & & $-66,58$ & 0,45 & & 0,22 & & 6,04 & & 0 \\
\hline & 3,75 & & 0,01 & & & $-5,06$ & 0,03 & & 1,28 & & 0 \\
\hline & 13,05 & & & & 0,05 & & 0,03 & & & $-13,13$ & 0 \\
\hline Subtotal & 76,66 & $-15,23$ & 0,01 & $-66,58$ & 7,28 & $-5,06$ & 6,37 & & 9,69 & $-13,13$ & 0 \\
\hline \multirow[t]{4}{*}{ 4. Derivativos } & & $-88,90$ & & & & & & & 88,90 & & 0 \\
\hline & 0,95 & & & & & & & & & $-0,95$ & 0 \\
\hline & & & & & 7,05 & & & & & $-7,05$ & 0 \\
\hline & & & & & & & 3,10 & & & $-3,10$ & 0 \\
\hline Subtotal & 0,95 & $-88,90$ & & & 7,05 & & 3,10 & & 88,90 & $-11,10$ & 0 \\
\hline \multirow[t]{5}{*}{ 5. Empréstimos } & & $-14,19$ & 9,54 & & 0,58 & & & & 4,08 & & 0 \\
\hline & 3,03 & & & $-4,94$ & & & & & 1,90 & & 0 \\
\hline & 44,22 & & & & & $-48,03$ & 0,63 & & 3,18 & & 0 \\
\hline & 29,76 & & 0,00 & & 1,53 & & & $-31,33$ & 0,04 & & 0 \\
\hline & 1,23 & & 0,21 & & 0,02 & & 0,05 & & & $-1,51$ & 0 \\
\hline Subtotal & 78,24 & $-14,19$ & 9,75 & $-4,94$ & 2,13 & $-48,03$ & 0,68 & $-31,33$ & 9,20 & $-1,51$ & 0 \\
\hline \multirow[t]{3}{*}{ 6. Ações e Outras Participações } & & $-42,54$ & 3,32 & & 16,59 & & 14,51 & & 8,12 & & 0 \\
\hline & 9,22 & & 7,81 & & & $-50,40$ & 6,06 & & 27,31 & & 0 \\
\hline & 1,10 & & 0,07 & & 4,34 & & 1,55 & & & $-7,05$ & 0 \\
\hline Subtotal & 10,32 & $-42,54$ & 11,20 & 0,00 & 20,93 & $-50,40$ & 22,12 & & 35,43 & $-7,05$ & 0 \\
\hline 7. Reservas técnicas de seguros & & $-100,00$ & 0,05 & & 1,60 & & 98,24 & & 0,12 & & 0 \\
\hline \multirow[t]{5}{*}{ 8. Outros débitos/créditos } & & $-9,81$ & 3,63 & & 2,50 & & 2,54 & & 1,14 & & 0 \\
\hline & 6,98 & & & $-25,77$ & 13,12 & & 5,65 & & 0,01 & & 0 \\
\hline & 4,43 & & 14,32 & & & $-30,56$ & 4,86 & & 6,94 & & 0 \\
\hline & 2,41 & & 13,70 & & 13,30 & & & $-29,41$ & 0,00 & & 0 \\
\hline & 0,08 & & & & 4,39 & & & & & $-4,46$ & 0 \\
\hline Subtotal & 13,90 & $-9,81$ & 31,64 & $-25,77$ & 33,31 & $-30,56$ & 13,06 & $-29,41$ & 8,09 & $-4,46$ & 0 \\
\hline
\end{tabular}

Fonte: Elaboração própria com base em dados de IBGE (Contas Nacionais).

Nessa tabela, o valor do estoque de cada instrumento foi igualado a 100, o que permite analisar a composição, pelo lado passivo e ativo, do mercado de cada tipo de instrumento ${ }^{25}$. Como os ativos entram com valor positivo e os passivos com valor negativo, a soma de cada linha é zero: os passivos emitidos pelas unidades componentes

\footnotetext{
${ }^{25}$ Os valores em reais correntes podem ser solicitados aos autores.
} 
de um setor, não tendo sido adquiridas por outras unidades do mesmo setor, estão necessariamente (não sendo explicitadas as discrepâncias estatísticas) registrados como ativos de outros setores.

A primeira linha da matriz parece provir diretamente do mundo simplificado dos modelos: só um setor (as empresas financeiras e, de fato, entre elas, só o Banco Central) possui ouro monetário e direitos especiais de saque, registrados como passivos do resto do mundo.

O segundo instrumento, numerário e depósitos, já apresenta um quadro mais complicado. Somente empresas financeiras (aqui eno resto do mundo) emitem passivos na forma de numerário e depósitos, que são, porém, ativos financeiros de todos os demais setores.

Em 2009, quase metade $(48,46 \%)$ das posições ativas em numerário e depósitos cabia à administração pública. Isso é explicado, em boa parte, pela importância da conta única do Tesouro no Banco Central2 ${ }^{26}$. As famílias e ISFLSF ("famílias", doravante, para simplificar) e as empresas nãofinanceiras, no essencial, dividiam o restante da posição ativa no instrumento.

A Tabela 3 traz o valor e a composição (do lado dos ativos) da riqueza financeira em 2009. Os números relativos às posições intersetoriais (ou consolidadas) provêm da matriz de patrimônio financeiro. Os números totais, que incluem as posições intrassetoriais (e são, portanto, iguais ou superiores aos primeiros), provêm da conta de patrimônio de 2009. O cálculo é simples: deduzindo-se dos números totais da conta de patrimônio os números consolidados da matriz, obtêm-se os números correspondentes às posições intrassetoriais.

Como evidencia a coluna 4 (Tabela 3), o peso relativo do primeiro instrumento era (e é) muito pequeno: apenas $0,08 \%$ das posições detidas intersetorialmente (e $0,05 \%$ da riqueza financeira total $)^{27}$.

Numerário e depósitos, por seu turno, representavam 13,76\% da posição intersetorial (e 13,69\% do total de ativos financeiros). Aqui, as posições intrassetoriais (cuja análise será retomada adiante) já se mostravam significativas (atingindo $30 \%$ das posições totais do setor).

${ }^{26}$ Em 2009, a administração pública possuía R \$ 847,8 bilhões em numerário e depósitos. Entretanto, segundo a Demonstração Financeira do Banco Central do mesmo ano, o valor da Conta Única do Tesouro Nacional era de R \$ 406,4 bilhões. Havia, portanto, disponibilidades significativas, das várias esferas do governo, "estacionadas" em outras contas.

${ }^{27}$ A coluna 3 (100\%) expressa o fato de que a posição intersetorial (do Banco Central contra o resto do mundo) equivalia à posição total. 
Tabela 3 - Composição da riqueza financeira (ativos, 2009, R\$ correntes e \%)

\begin{tabular}{|c|c|c|c|c|c|}
\hline 1. Ouro Monetário e DES & 9.896 & 9.896 & 100,0 & 0,08 & 0,05 \\
\hline 3. Títulos, exceto ações & 3.021 .069 & 3.427 .915 & 88,1 & 23,76 & 18,76 \\
\hline 4. Derivativos & 6.682 & 6.682 & 100,0 & 0,05 & 0,04 \\
\hline 5. Empréstimos & 1.903 .139 & 3.370 .909 & 56,5 & 14,97 & 18,45 \\
\hline 6. Ações e Outras Participações & 3.513 .550 & 5.742 .540 & 61,2 & 27,63 & 31,43 \\
\hline
\end{tabular}

Fonte: Elaboração própria com base em dados de IBGE (Contas Nacionais).

A terceira rubrica, títulos, exceto ações, de maior peso do que as anteriores $(23,76 \%$ da posição financeira intersetorial; $31,43 \%$ da riqueza financeira), é ainda mais complexa. Os títulos são instrumentos de financiamento de todos os setores, à exceção das famílias. Porém, os dados de 2009 (Tabela 2) retratam um mercado que, no essencial, tinha na ponta devedora a administração pública (66,58\% do estoque total de títulos) e na ponta credora o setor financeiro ( $76,66 \%$ do estoque).

Após os títulos públicos, seguiam-se os títulos emitidos pelas próprias instituições financeiras e pelo resto do mundo (respectivamente, 15,23\% e 13,13\%). A participação das empresas não financeiras no estoque de títulos em circulação era de apenas 5,06\%, atestando a pequena relevância do mercado de capitais, no Brasil, como instrumento de financiamento das firmas.

A Tabela 4 apresenta uma nova transmutação da matriz de patrimônio financeiro. Dessa vez, porém, o estoque de cada tipo de passivo, por parte de cada setor institucional, é igualado a 100. Torna-se fácil, assim, observar como cada instrumento é absorvido pelos demais setores.

O mercado de títulos públicos era dominado pelas empresas financeiras e pelo resto do mundo, que detinham, respectivamente, $89,91 \%$ e $9,08 \%$ da oferta; a participação das empresas não financeiras e das famílias, como se sabe, ocorre fundamentalmente por meio da aquisição de cotas dos fundos de investimento administrados pelo setor financeiro.

Já para o segmento de títulos emitidos pelas empresas financeiras, os principais supridores de fundos eram as empresas não financeiras e as famílias (respectivamente, $44,53 \%$ e $39,93 \%)$.

Os títulos emitidos pelas empresas não financeiras eram, no essencial, destinados às empresas financeiras $(74,04 \%)$ e ao resto do mundo $(25,21 \%)$. As empresas finan- 
ceiras respondiam pela quase totalidade $(99,41 \%)$ da demanda pelos títulos de emissão externa (vale lembrar que aqui estão contabilizadas as reservas externas do Banco Central).

As linhas destinadas aos derivativos registram apenas as posições de setores nacionais vis-à-vis do resto do mundo: posições ativas e passivas (estas, as mais significativas) das empresas financeiras e posições ativas das empresas não financeiras e das famílias $^{28}$.

O estoque de empréstimos representou, em 2009 (Tabela 3), 14,97\% das posições financeiras intersetoriais (ou $18,45 \%$ da riqueza financeira). Obviamente, nesse mercado, a posição ativa é dominada pelas empresas financeiras. Em 2009, estas respondiam por $78,24 \%$ da concessão total de empréstimos (Tabela 2). Seguiam-se o governo (cujos empréstimos - 9,54\% do total - eram, em sua maior parte, direcionados ao setor financeiro $\left.{ }^{29}\right)$ e o resto do mundo $(9,20 \%$, direcionados às empresas não financeiras, em primeiro lugar e, em segundo, às empresas financeiras). Não surpreendentemente, os principais tomadores foram as empresas não financeiras ( $48,03 \%$ do total) e as famílias (31,33\%), ainda que não fosse desprezível a proporção dos empréstimos tomados pelas próprias empresas financeiras (14,19\%, provenientes, como referido anteriormente, da administração pública e do resto do mundo).

Empresas e famílias tinham, no essencial, dívida interna (92,07\% e 94,98\% de seus passivos na forma de empréstimos, respectivamente; Tabela 4). A proporção era mais baixa $(61,46 \%)$ no caso da (pequena) dívida em empréstimos da administração pública (que, como mostra a Tabela 2, representava apenas 4,94\% do total de passivos nesse instrumento).

Os instrumentos incluídos em ações e outras participações representavam, em 2009 , a mais alta parcela da posição intersetorial $(27,63 \%$, ou $31,43 \%$ da riqueza financeira total; Tabela 3). Entretanto, antes que se cogite revisar a dimensão do mercado de capitais no Brasil, é conveniente relembrar que, seguindo as diretrizes do SNA, a rubrica incorpora, além das ações cotadas e de outros tipos de participação de capital (inclusive ações não cotadas), um item de natureza muito diferente: as cotas dos fundos de investimento.

${ }^{28}$ Segundo esclarecimentos recebidos do Banco Central, embora o SNA 1993 agregasse os derivativos aos títulos, optou-se, no Brasil, por explicitar os derivativos contratados com o resto do mundo. Com a adoção do SNA 2008, todos os derivativos serão apresentados em item específico.

${ }^{29}$ E, nele, a instituições como o BNDES, o Banco do Brasil e a Caixa Econômica Federal. Ressalte-se, uma vez mais, o fato de que a matriz só apresenta relações intersetoriais, eliminando, por exemplo, as dívidas (consideráveis) entre os vários níveis de governo e com fundos, como o Fundo de Garantia do Tempo de Serviço - FGTS - e o Programa de Integração Social - PIS (IBGE, 2011, p. 15-16). 
Infelizmente, os dados de patrimônio não apresentam a decomposição do item. Porém, é possível recorrer aos dados de fluxo das contas financeiras para obter algum esclarecimento adicional. Na média dos anos disponíveis (2005-2009), as ações e outras participações responderam por $23,9 \%$ da emissão líquida de passivos. Apenas 2,3\% couberam, porém, às ações cotadas; as ações não cotadas e outras participações responderam por $10,5 \%$ e os fundos de investimento por 11,1\%. Essa média, é claro, esconde variações anuais, respondendo à sucessão das conjunturas ${ }^{30}$. Ainda que tais variações tendam a ser mais relevantes para os fluxos do que para os estoques (que podem, no entanto, sofrer também variações significativas por conta de ganhos/perdas de capital), a média sugere que, também no que diz respeito aos estoques, as ações cotadas tenham participação diminuta no total de passivos. Convém lembrar que a retenção de lucros vem a ser, em boa parte dos países, uma das principais fontes de financiamento das empresas, e que os lucros retidos incorporam-se ao seu capital (na forma das outras participações contabilizadas na rubrica).

A posição passiva das empresas não financeiras (50,40\% do total do instrumento; Tabela 2) corresponde a ações e, principalmente, a ações não cotadas e outras participações. Aqui, mais uma vez, trata-se de uma inferência baseada nas contas financeiras. Na média do período 2005-2009, as ações cotadas representaram apenas 22,5\% das emissões líquidas desse instrumento por parte das empresas não financeiras ${ }^{31}$. Já no caso da posição passiva das empresas financeiras (44,22\% do total), as cotas de fundos de investimento devem representar parcela expressiva do estoque. Na média do período 2005-2009, o valor das emissões líquidas de cotas de fundos de investimento foi de 72,8\% do total das emissões líquidas de ações e outras participações (ou de 89,9\%, se excluído o ano de 2008).

É interessante destacar que, no caso das empresas não financeiras, as injeções de capital provinham, em sua maioria (54,18\%, Tabela 4 ), do resto do mundo, refletindo o estoque de investimento direto externo no país. Em ordem de importância decrescente, seguiam-se as empresas financeiras (18,29\%), a administração pública (15,50\%) e, finalmente, as famílias (12,03\%). No caso das empresas financeiras, predominavam as aplicações (presumivelmente, em fundos de investimento) provenientes das empresas não financeiras (38,99\%). Vinham, na sequência, as participações das famílias $(34,11 \%)$, do resto do mundo (19,09\%) e do governo $(7,81 \%)$.

\footnotetext{
${ }^{30}$ Em 2008, por exemplo, o peso das ações não cotadas e outras participações foi de $17,2 \%$ das emissões totais de passivos, ao passo que o peso das participações em fundos caiu para 0,3\%.

31 As emissões líquidas de cotas de fundos de investimento são nulas: só teriam valor positivo caso fossem incluídos no agregado os eventuais dados de braços financeiros de empresas não financeiras.
} 
Tabela 4 - Matriz de patrimônio financeiro de 2009 - distribuição intersetorial dos passivos de cada setor (\%)

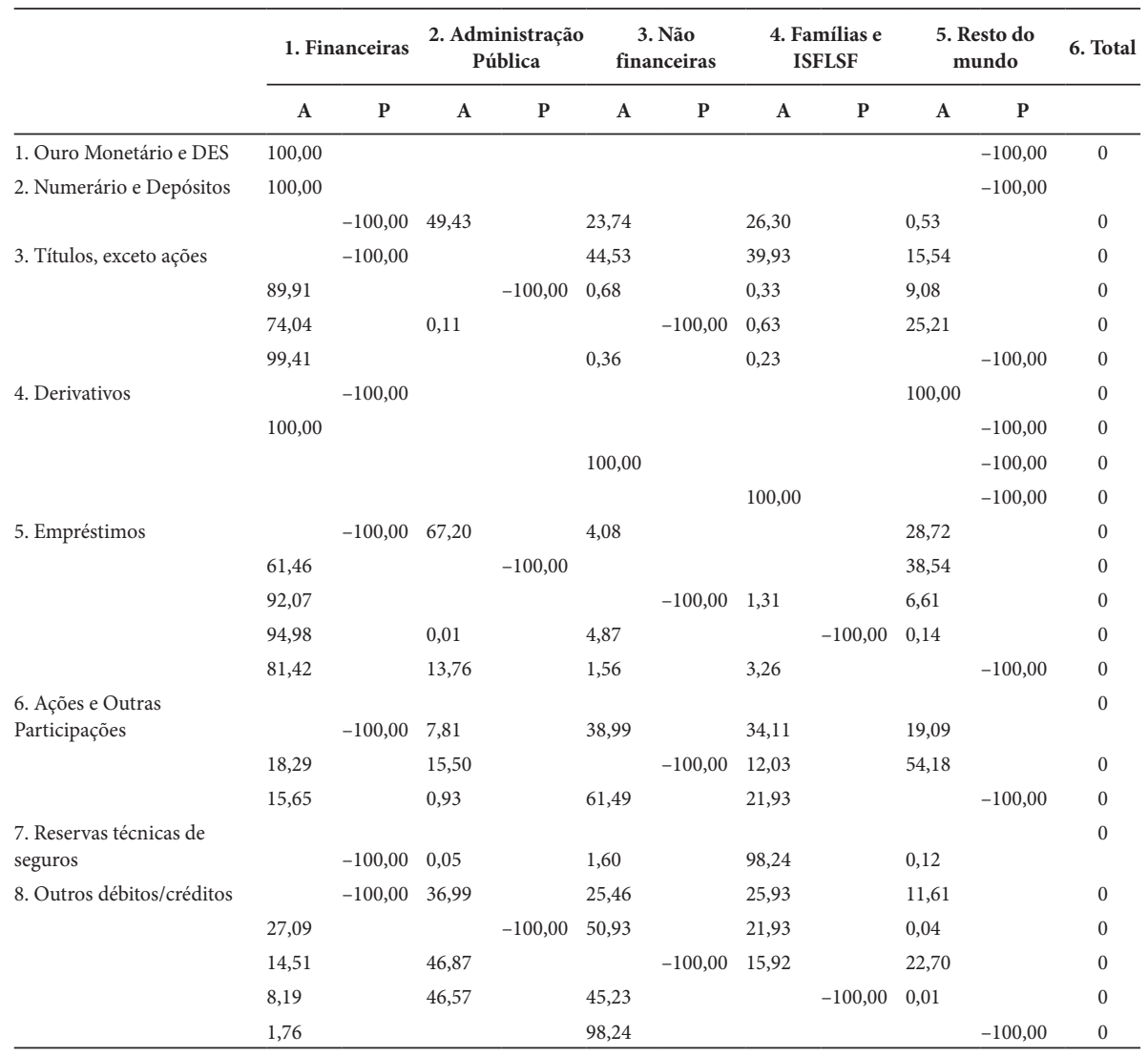

Fonte: Elaboração própria com base em dados de IBGE (Contas Nacionais).

Depois dos títulos, as ações e outras participações são o instrumento financeiro de maior importância nas aplicações no exterior de residentes no país. Enquanto os títulos, como já ressaltado, pertencem fundamentalmente a empresas financeiras (entre as quais o Banco Central), as disponibilidades externas em ações e outras participações pertenciam a empresas não financeiras $(61,49 \%$ do total), famílias $(21,93 \%)$ e empresas financeiras (15,65\%). Seria interessante conhecer melhor a composição dessas aplicações.

As reservas técnicas de seguros são quase que, exclusivamente, um assunto entre empresas financeiras (que emitem a totalidade dos passivos) e as famílias (que adquirem a quase totalidade dos ativos).

O instrumento remanescente, outros débitos/créditos, tem peso significativo (14,76\% da posição intersetorial e 14,09\% da riqueza financeira). Sua interpretação é problemática, por várias razões. Em primeiro lugar, a heterogeneidade da rubrica, que inclui, 
além do crédito comercial (possivelmente eliminado na consolidação do setor), valores a pagar, atrasados e de ações na Justiça. Em segundo lugar, o fato de que a categoria é o destino de todo o resíduo estatístico, cujo valor não é divulgado. Em todo caso, pode-se registrar que os principais detentores desses passivos (Tabela 4) são as empresas não financeiras (30,56\%), as famílias (29,41\%), a administração pública (25,77\%), seguidos pelas empresas financeiras $(9,81 \%)$. Pelo lado do ativo, destacam-se, uma vez mais, as empresas não financeiras $(33,31 \%)$ e a administração pública $(31,64 \%)$, seguidos pelo setor financeiro e pelas famílias (respectivamente, 13,90\% e 13,06\%).

\subsubsection{A ÓTICA DOS SETORES; POSIÇÕES INTER E INTRASSETORIAIS}

A Tabela 5 é a terceira e última transfiguração da matriz de patrimônio. Cada coluna agora soma 100, revelando a composição intersetorial de ativos e passivos do setor institucional. Essa composição pode ser interpretada como uma medida da exposição de cada setor aos demais, no que concerne tanto a ativos quanto a passivos. Não deve ser confundida com a composição real (ou total) do portfólio de cada setor (Tabela 6), a qual inclui as posições em ativos adquiridos de (ou vendidos a) agentes do próprio setor.

A diferença entre a composição intersetorial e a composição real (ou total) pode ser evidenciada pelo seguinte exemplo: segundo a Tabela 5, numerário e depósitos representavam, em 2009, somente $0,77 \%$ do total de ativos das empresas financeiras. O valor é baixo porque, aqui, somente estão contabilizadas as disponibilidades contra o resto do mundo; a consolidação eliminou os depósitos intrassetoriais. Tomando em consideração, como na Tabela 6, a totalidade dos ativos do setor - o que implica tomar em conta, entre outras posições, os volumosos depósitos interbancários constata-se que a fração correspondente ao instrumento era de 8,48\%. A diferença é considerável.

O tema da consolidação será retomado abaixo. Importa agora ressaltar um resultado que, não sendo surpreendente, não deixa de ser reconfortante. A Tabela 5 parece legitimar o emprego do corte por setores institucionais: as relações patrimoniais variam de forma significativa para cada setor. Em particular, percebe-se como ainda são diversas as inserções de empresas financeiras e não financeiras, a despeito do debate acerca da financeirização das últimas.

O financiamento das empresas não financeiras se dava, em sua maior parte (51,92\%; Tabela 5), por meio de ações e outras participações. Frações menores cabiam aos empréstimos (26,79\%) e aos títulos (somente 4,48\%). As aplicações em ações e outras participações emitidas por empresas financeiras (que devem consistir, em es- 
sência, em cotas de fundos de investimento) eram o mais importante (28,59\%) ativo financeiro. Destacavam-se, ainda, as aplicações em numerário e depósitos (19,98\%), em títulos (10,79\%) e em ações e outras participações no resto do mundo $(7,48 \%)^{32}$.

Tabela 5 - Matriz de patrimônio financeiro de 2009 - composição intersetorial do portfólio dos setores institucionais (\%)

\begin{tabular}{|c|c|c|c|c|c|c|c|c|c|c|}
\hline & \multicolumn{2}{|c|}{ 1. Financeiras } & \multicolumn{2}{|c|}{$\begin{array}{l}\text { 2. Administração } \\
\text { Pública }\end{array}$} & \multicolumn{2}{|c|}{$\begin{array}{l}\text { 3. Não } \\
\text { financeiras }\end{array}$} & \multicolumn{2}{|c|}{$\begin{array}{l}\text { 4. Famílias e } \\
\text { ISFLSF }\end{array}$} & \multicolumn{2}{|c|}{$\begin{array}{l}\text { 5. Resto } \\
\text { do mundo }\end{array}$} \\
\hline & A & $\mathbf{P}$ & A & $\mathbf{P}$ & A & $\mathbf{P}$ & A & $\mathbf{P}$ & A & $\mathbf{P}$ \\
\hline 1. Ouro Monetário e DES & 0,22 & & & & & & & & & 1,23 \\
\hline \multirow[t]{2}{*}{ 2. Numerário e Depósitos } & 0,77 & & & & & & & & & 4,27 \\
\hline & & 36,00 & 41,95 & & 19,98 & & 19,59 & & 0,48 & \\
\hline \multirow[t]{4}{*}{ 3. Títulos, exceto ações } & & 9,66 & & & 10,05 & & 7,98 & & 3,80 & \\
\hline & 40,43 & & & 77,70 & 0,67 & & 0,29 & & 9,71 & \\
\hline & 2,53 & & 0,01 & & & 4,48 & 0,04 & & 2,05 & \\
\hline & 8,81 & & & & 0,07 & & 0,04 & & & 49,46 \\
\hline Sub-total & 51,78 & 9,66 & 0,01 & 77,70 & 10,79 & 4,48 & 8,35 & & 15,56 & 49,46 \\
\hline \multirow[t]{4}{*}{ 4. Derivativos } & & 0,12 & & & & & & & 0,32 & \\
\hline & 0,001 & & & & & & & & & 0,01 \\
\hline & & & & & 0,02 & & & & & 0,06 \\
\hline & & & & & & & 0,01 & & & 0,03 \\
\hline \multirow[t]{5}{*}{ 5. Empréstimos } & & 5,67 & 8,98 & & 0,54 & & & & 4,13 & \\
\hline & 1,29 & & & 3,63 & & & & & 1,93 & \\
\hline & 18,82 & & & & & 26,79 & 0,52 & & 3,21 & \\
\hline & 12,66 & & 0,00 & & 1,43 & & & 51,94 & 0,04 & \\
\hline & 0,52 & & 0,20 & & 0,02 & & 0,04 & & & 3,58 \\
\hline Sub-total & 33,29 & 5,67 & 9,18 & 3,63 & 1,99 & 26,79 & 0,56 & 51,94 & 9,31 & 3,58 \\
\hline \multirow[t]{3}{*}{ 6. Ações e Outras Participações } & & 31,37 & 5,78 & & 28,59 & & 22,15 & & 15,18 & \\
\hline & 7,24 & & 13,58 & & & 51,92 & 9,26 & & 51,04 & \\
\hline & 0,87 & & 0,11 & & 7,48 & & 2,36 & & & 30,91 \\
\hline Subtotal & 8,11 & 31,37 & 19,47 & & 36,07 & 51,92 & 33,76 & & 66,22 & 30,91 \\
\hline 7. Reservas técnicas de seguros & & 13,32 & 0,01 & & 0,50 & & 27,07 & & 0,04 & \\
\hline \multirow[t]{5}{*}{ 8. Outros débitos/créditos } & & 3,86 & 3,37 & & 2,30 & & 2,07 & & 1,14 & \\
\hline & 2,93 & & & 18,67 & 12,08 & & 4,61 & & 0,01 & \\
\hline & 1,86 & & 13,30 & & & 16,81 & 3,97 & & 6,92 & \\
\hline & 1,01 & & 12,72 & & 12,24 & & & 48,06 & 0,00 & \\
\hline & 0,03 & & & & 4,04 & & & & & 10,45 \\
\hline Subtotal & 5,83 & 3,86 & 29,38 & 18,67 & 30,66 & 16,81 & 10,64 & 48,06 & 8,07 & 10,45 \\
\hline Total & 100,00 & 100,00 & 100,00 & 100,00 & 100,00 & 100,00 & 100,00 & 100,00 & 100,00 & 100,00 \\
\hline
\end{tabular}

Fonte: Elaboração própria com base em dados de IBGE (Contas Nacionais).

32 Somente uma pesquisa mais aprofundada - acompanhando séries mais longas, tanto brasileiras quanto internacionais - permitiria dizer se a ponderação de ativos como numerário e títulos (além de cotas em fundos de investimento) pode ser tomada como uma proxy da preferência pela liquidez - e se indicam uma preferência pela liquidez relativamente elevada. 


\section{Tabela 6 - Setores institucionais: composição patrimonial (\% do total de ativos e passivos)}

\begin{tabular}{lllllllllllllllll}
\hline & 2004 & & 2005 & & 2006 & & 2007 & & 2008 & & 2009 & Média 04-09 \\
\hline & A & P & A & P & A & P & A & P & A & P & A & P & A & P \\
\hline
\end{tabular}

Empresas financeiras

(exclusive Banco Central)

Numerário e depósitos

Títulos, exceto ações

Empréstimos

Ações e outras participações

Reservas técnicas de seguros

Outros débitos/créditos

Total

Administração pública

Numerário e depósitos

Títulos, exceto ações

Empréstimos

Ações e outras participações

Reservas técnicas de seguros

Outros débitos/créditos

Total

\section{Empresas não financeiras}

Numerário e depósitos

Títulos, exceto ações

Empréstimos

Ações e outras participações

Reservas técnicas de seguros

Outros débitos/ créditos

Total

\section{Famílias e ISFLSF}

Numerário e depósitos

Títulos, exceto ações

Empréstimos

Ações e outras participações

Reservas técnicas de seguros

Outros débitos/créditos

Total

Resto do mundo

Ouro monetário e DES

Numerário e depósitos

Títulos, exceto ações

Empréstimos

Ações e outras participações

Reservas técnicas de seguros

Outros débitos/créditos

$\begin{array}{rrrrrrrrrrrrrr}7,4 & 19,1 & 8,1 & 19,5 & 9,1 & 19,6 & 11,1 & 19,3 & 9,5 & 14,7 & 9,7 & 17,0 & 9,1 & 18,2 \\ 30,5 & 10,0 & 31,0 & 10,9 & 30,2 & 11,6 & 26,9 & 11,4 & 26,2 & 16,2 & 25,1 & 13,8 & 28,3 & 12,3 \\ 26,6 & 12,3 & 25,4 & 11,2 & 26,0 & 11,3 & 28,8 & 13,6 & 32,4 & 16,7 & 33,8 & 18,0 & 28,8 & 13,9 \\ 26,0 & 38,9 & 27,4 & 40,7 & 27,7 & 42,0 & 27,6 & 42,1 & 24,3 & 37,2 & 25,3 & 38,3 & 26,4 & 39,9 \\ 0,0 & 9,4 & 0,0 & 8,8 & 0,0 & 8,5 & 0,0 & 8,0 & 0,0 & 8,5 & 0,0 & 8,1 & 0,0 & 8,5 \\ 9,5 & 10,2 & 8,1 & 9,1 & 6,9 & 6,9 & 5,6 & 5,7 & 7,6 & 6,7 & 6,0 & 4,8 & 7,3 & 7,2\end{array}$

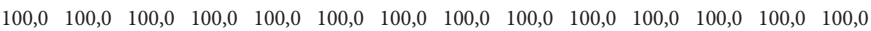

$$
\begin{array}{rrrrrrrrrrrrrr}
20,9 & - & 23,6 & - & 24,1 & - & 25,3 & - & 25,1 & - & 32,1 & - & 25,2 & - \\
2,2 & 62,0 & 2,4 & 64,4 & 2,3 & 64,2 & 2,4 & 64,1 & 3,3 & 63,6 & 2,7 & 64,9 & 2,6 & 63,9 \\
25,2 & 26,2 & 23,3 & 24,2 & 22,5 & 22,9 & 21,0 & 20,3 & 24,1 & 20,2 & 24,7 & 17,5 & 23,5 & 21,9 \\
12,0 & - & 13,4 & - & 15,6 & - & 17,1 & - & 15,2 & - & 14,9 & - & 14,7 & - \\
0,0 & - & 0,0 & - & 0,0 & - & 0,0 & - & 0,0 & - & 0,0 & - & 0,0 & - \\
39,6 & 11,8 & 37,3 & 11,4 & 35,6 & 12,9 & 34,3 & 15,6 & 32,3 & 16,2 & 25,6 & 17,7 & 34,1 & 14,3
\end{array}
$$

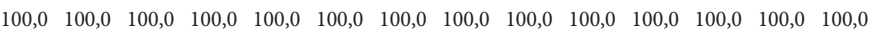

$$
\begin{array}{rrrrrrrrrrrrrr}
8,7 & - & 8,9 & - & 9,3 & - & 9,6 & - & 10,2 & - & 9,2 & - & 9,3 & - \\
4,2 & 3,2 & 4,2 & 2,6 & 4,0 & 2,5 & 3,2 & 2,1 & 6,3 & 3,0 & 5,0 & 2,7 & 4,5 & 2,7 \\
4,6 & 13,0 & 4,7 & 13,2 & 4,5 & 13,8 & 1,5 & 11,6 & 1,4 & 17,1 & 1,2 & 15,7 & 3,0 & 14,1 \\
51,3 & 49,9 & 53,2 & 53,7 & 57,1 & 58,0 & 61,2 & 64,1 & 52,6 & 54,8 & 58,2 & 62,3 & 55,6 & 57,2 \\
0,2 & - & 0,2 & - & 0,2 & - & 0,2 & - & 0,2 & - & 0,2 & - & 0,2 & - \\
30,9 & 33,8 & 28,8 & 30,4 & 24,9 & 25,7 & 24,2 & 22,2 & 29,2 & 25,1 & 26,2 & 19,3 & 27,4 & 26,1 \\
100,0 & 100,0 & 100,0 & 100,0 & 100,0 & 100,0 & 100,0 & 100,0 & 100,0 & 100,0 & 100,0 & 100,0 & 100,0 & 100,0
\end{array}
$$

$$
\begin{array}{rrrrrrrrrrrrrrr}
16,7 & - & 16,2 & - & 16,9 & - & 17,6 & - & 19,9 & - & 19,9 & - & 17,9 & - \\
3,4 & - & 4,2 & - & 4,7 & - & 4,4 & - & 9,4 & - & 8,3 & - & 5,7 & - \\
0,7 & 35,8 & 0,7 & 40,0 & 0,6 & 44,5 & 0,5 & 48,2 & 0,7 & 51,2 & 0,6 & 51,9 & 0,6 & 45,3 \\
30,1 & - & 33,2 & - & 37,0 & - & 38,8 & - & 31,2 & - & 33,6 & - & 34,0 & - \\
22,9 & - & 23,8 & - & 25,2 & - & 24,8 & - & 27,6 & - & 27,0 & - & 25,2 & - \\
26,1 & 64,2 & 21,9 & 60,0 & 15,6 & 55,5 & 13,9 & 51,8 & 11,1 & 48,8 & 10,6 & 48,1 & 16,5 & 54,7
\end{array}
$$

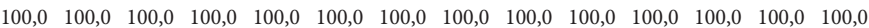

\begin{tabular}{rrrrrrrrrrrrrr}
$-0,1$ & 0,0 & $-0,1$ & 0,0 & $-0,1$ & 0,0 & $-0,1$ & 0,0 & $-0,1$ & 0,0 & $-0,5$ & 0,0 & $-0,2$ & 0,0 \\
0,7 & 21,8 & 0,7 & 17,7 & 0,7 & 12,9 & 0,5 & 8,0 & 0,6 & 6,5 & 0,5 & 6,8 & 0,6 & 12,3 \\
23,8 & 26,2 & 21,5 & 29,6 & 17,2 & 34,6 & 14,4 & 44,7 & 18,5 & 48,9 & 16,0 & 48,9 & 18,6 & 38,8 \\
20,7 & 0,5 & 12,9 & 0,5 & 12,1 & 0,5 & 9,7 & 7,0 & 14,9 & 3,2 & 9,4 & 3,5 & 13,3 & 2,5 \\
49,7 & 39,2 & 60,1 & 41,7 & 64,7 & 43,2 & 69,7 & 31,7 & 55,8 & 29,5 & 66,6 & 30,5 & 61,1 & 36,0 \\
0,1 & 0,0 & 0,1 & 0,0 & 0,1 & 0,0 & 0,0 & 0,0 & 0,1 & 0,0 & 0,0 & 0,0 & 0,1 & 0,0 \\
5,3 & 12,4 & 4,8 & 10,6 & 5,3 & 8,8 & 5,7 & 8,5 & 10,2 & 11,9 & 8,1 & 10,3 & 6,6 & 10,4 \\
\hline
\end{tabular}

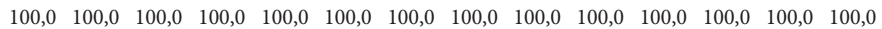

Fonte: Elaboração própria com base em dados de IBGE (Contas Nacionais). 
O portfólio das empresas financeiras, evidentemente o mais complexo, mostrava numerário e depósitos (36,00\%), e ações e outras participações (31,37\%) como as fontes mais relevantes ${ }^{33}$. Os títulos, que representam apenas $9,66 \%$ dos passivos, respondiam por $51,78 \%$ dos ativos, participação que superava largamente a dos empréstimos (33,29\%). Dada a importância particularmente significativa das transações financeiras entre empresas (financeiras ou não), essas porcentagens são bastante diferentes quando se consideram (como na Tabela 8) os ativos e passivos totais.

Tabela 7 - Posições inter e intrassetoriais como razão da posição total (2009, \%)

\begin{tabular}{lccrrrr}
\hline & \multicolumn{2}{c}{ Não financeiras } & \multicolumn{2}{c}{ Financeiras } & \multicolumn{2}{c}{ Administração Pública } \\
\cline { 2 - 7 } & \multicolumn{1}{c}{$\mathbf{A}$} & $\mathbf{P}$ & $\mathbf{A}$ & $\mathbf{P}$ & \multicolumn{1}{c}{$\mathbf{A}$} & \multicolumn{1}{c}{ P } \\
\hline Intersetorial & 45,1 & 57,7 & 51,1 & 52,6 & 76,4 & 80,6 \\
Intrassetorial & 54,9 & 42,3 & 48,9 & 47,4 & 23,6 & 19,4 \\
Total & 100,0 & 100,0 & 100,0 & 100,0 & 100,0 & 100,0 \\
\hline
\end{tabular}

Fonte: Elaboração própria com base em dados de IBGE (Contas Nacionais).

As famílias, basicamente, obtêm financiamento dos bancos (seus passivos na forma de outros débitos/créditos devem expressar, em larga medida, ações na justiça movidas por outros setores, particularmente pelas empresas não financeiras e pela administração pública) ${ }^{34}$. Pelo lado do ativo, predominavam, em 2009, as ações e outras participações $(33,76 \%)$, consistindo principalmente em aplicações junto a empresas não financeiras $(22,15 \%$ do ativo), o que sugere o predomínio de cotas de fundos de investimento. Parte importante $(27,07 \%)$ da riqueza das famílias estava aplicada na forma de reservas técnicas de seguros. Também relevantes eram as aplicações em numerário e depósitos $(19,59 \%)$ e títulos $(8,35 \%)$.

\footnotetext{
${ }^{33}$ Como antes mencionado, qualquer hipótese interpretativa a respeito das empresas financeiras deve ser lida com cautela, dada a distorção derivada da inclusão do Banco Central no agregado. Em 2009, por exemplo, o ativo total - não muito diferente do ativo financeiro - do Banco Central montava a quase R\$ 1,2 trilhões, ou $13,2 \%$ dos ativos totais do setor. Outro corte de indiscutível importância, particularmente no período pós-crise, é o que separa os bancos públicos das demais instituições financeiras. No mesmo ano, o Banco do Brasil (conglomerado financeiro), a Caixa Econômica Federal (instituição independente) e o BNDES possuíam ativos, respectivamente, no valor de R $\$ 692$ bilhões (ou 9,1\% do ativo das empresas financeiras exclusive Banco Central), $\mathrm{R} \$ 342$ bilhões (4,5\%) e $\mathrm{R} \$ 379$ bilhões (4,9\%).

${ }^{34}$ Como se pode apreciar na Tabela 5 , as participações desse instrumento são significativas no passivo e no ativo de todos os setores institucionais, particularmente para as famílias, a administração pública e as empresas não financeiras. Dada a natureza do instrumento, já comentada acima, não se irá aqui além do registro desse fato.
} 
O passivo da administração pública, no essencial, fora contraído pela emissão de títulos (77,7\%). No outro lado do balanço, avultavam, além das posições em numerário e depósitos (41,95\%), aquelas em ações e outras participações.

Finalmente, percebe-se que, no relacionamento entre os agentes do resto do mundo e os residentes no Brasil, os primeiros concentravam suas aquisições em ações e outras participações $(66,22 \%)$ e em títulos (15,56\%); para os últimos, a ordem era a inversa, sendo mais importantes as aquisições de títulos (49,46\%), seguidas pelas de ações e outras participações (30,91\%).

As porcentagens da Tabela 6 foram calculadas a partir das contas de patrimônio, que contabilizam, para o período 2004-2009, a totalidade das posições dos setores ${ }^{35}$. Perdem-se de vista, aqui, as relações entre os setores. A apresentação dos números anuais - bem como da média do período - tem por objetivo sugerir que, a despeito de diferenças não desprezíveis em várias células, não é absurdo explorar (como se fez neste texto) o ano de 2009 para ilustrar as características da riqueza financeira no Brasil.

É conveniente retornar agora à Tabela 3. Esta mostra que, em todos os instrumentos financeiros (coluna 3), as posições intersetoriais superavam as intrassetoriais (o que não deixa de ratificar, uma vez mais, a abordagem setorial). Em três instrumentos, as posições intrassetoriais eram nulas (ouro monetário e DES; derivativos) ou próximas de zero (reservas técnicas de seguros). Porém, nos demais instrumentos (que, aliás, têm os maiores pesos na riqueza financeira), as posições intrassetoriais tinham importância significativa: eram 43,5\% dos empréstimos; 38,8\% das ações e outras participações; 30\% das posições em numerário e depósitos; $27,1 \%$ dos outros débitos/créditos; $11,9 \%$ dos títulos.

Os dados de patrimônio não permitem o cálculo das posições intrassetoriais das famílias (não por inexistirem, mas por serem contraídas de modo informal). No caso do resto do mundo, as posições intrassetoriais são, por construção, iguais a zero. Como mostra a Tabela 7, as posições intrassetoriais, em 2009, eram particularmente relevantes para as empresas não financeiras (54,9\% dos ativos e $42,3 \%$ dos passivos) e para as empresas financeiras (48,9\% e 47,4\%, respectivamente), tendo menor peso no caso da administração pública (23,6\% e 19,4\%).

Para compreender o significado dessas posições, é necessário comparar os valores consolidados da matriz de 2009 aos valores totais das contas de patrimônio do mesmo ano.

A maior posição intrassetorial, em termos absolutos ( $\mathrm{R}$ 1,9 trilhão), era a detida pelas empresas não financeiras em ações e outras participações. Há pelo menos quatro

\footnotetext{
${ }^{35}$ Novamente, o cotejo com as Demonstrações Financeiras do Banco Central (nesse caso, com os números de seu balanço patrimonial) permitiu excluí-lo do conjunto das demais empresas financeiras.
} 
outras formas de aquilatar a importância dessa posição, comparando-a com ativos e passivos totais, bem como com as posições ativa e passiva no instrumento ${ }^{36}$.

A comparação com os ativos totais é uma evidência das preferências dessas empresas no que concerne à escolha de ativos financeiros. A posição correspondia a 42,0\% dos ativos financeiros do setor, superando de longe as participações dos outros itens de maior peso (após débitos/créditos, com 26,2\%, ações e outras participações emitidas por empresas financeiras, com 12,0\%, e numerário e depósitos, com 9,2\%).

Em segundo lugar, ainda pelo lado do ativo, é possível destacar a predominância $(72,2 \%)$ dessas posições - que representam injeções de capital - em relação às aplicações no mesmo instrumento em outros setores: $22,0 \%$ em empresas financeiras (e em seus fundos de investimento) e 5,8\% no resto do mundo.

Em terceiro lugar, os dados mostram a importância dessas injeções de capital no passivo total do setor $(32,4 \%)$. De fato, trata-se da fonte mais importante, seguida (se abstrairmos o obscuro instrumento outros débitos/créditos, com 19,3\%) pelas injeções de capital provenientes do resto do mundo (16,2\%) e pelos empréstimos (15,7\%).

Em quarto lugar, a razão $(51,9 \%)$ entre a posição e os passivos em ações e outros instrumentos deixa mais clara a dominância, no instrumento, das relações patrimoniais internas ao setor.

Outras posições intrassetoriais vultosas eram aquelas das empresas financeiras, em ações e participações (17,8\% dos ativos e 17,3\% dos passivos), em empréstimos (respectivamente, 13,3\% e 12,9\%), em numerário e depósitos (8,4\% e 8,2\%) e em títu$\operatorname{los}(7,1 \%$ e $6,9 \%)$.

No que toca à administração pública, chamam a atenção, pela importância relativa, as posições intrassetoriais em empréstimos e em ações e participações (respectivamente, $17,7 \%$ do ativo e $14,9 \%$ do ativo) $)^{37}$.

A incorporação das posições intrassetoriais, na Tabela 6, não modifica a conclusão à qual se havia chegado a partir da análise da Tabela 5, acerca da importância das diferenças estruturais entre os setores institucionais (para uma análise mais detalhada das contas patrimoniais, ver IBGE [2011]). Comparando-se ambas as tabelas, constata-se que as maiores diferenças ocorrem no setor das empresas financeiras, dada a importância, no setor, de posições intrassetoriai sem todos os principais instrumentos.

\footnotetext{
${ }^{36}$ Não custa lembrar que, em cada setor, ativos e passivos financeiros têm valores diferentes e que, enquanto o valor dos ativos inclui aplicações no resto do mundo, o valor dos passivos dos setores nacionais inclui a parcela de propriedade de não-residentes.

${ }^{37}$ Em IBGE (2011, p. 15-16), encontra-se a explicação para a presença dos empréstimos nas posições ativas (e passivas): "corresponde às dívidas entre os níveis de governo e aos empréstimos de alguns fundos, como o Fundo de Garantia do Tempo de Serviço - FGTS - e o Programa de Integração Social - PIS (...). Estão considerados também os empréstimos para capitalização de empresas públicas".
} 


\section{OBSERVAÇÕES FINAIS}

O principal propósito deste texto foi o de mostrar tanto o potencial quanto as limitações dos dados analisados - provenientes, em sua maior parte, das contas financeira e de patrimônio financeiro e da matriz de patrimônio financeiro publicadas pelo IBGE em 2011 - para permitir um mapeamento do tamanho e da composição da riqueza financeira no Brasil. Os dados apresentados nas Tabelas 1-7 são as aproximações possíveis, no momento, para essas variáveis. O texto procurou enriquecer a apresentação desses dados pelo cálculo, para o ano de 2009, das posições financeiras intrassetoriais, bem como pelo cálculo da composição do patrimônio das empresas financeiras exclusive Banco Central.

A publicação de novas matrizes de patrimônio financeiro pelo Banco Central certamente permitirá um quadro mais claro da evolução da riqueza financeira no Brasil nos últimos anos - iluminando, em particular, as consequências patrimoniais da desaceleração da economia a partir de 2014. Infelizmente, entretanto, os economistas interessados no tema provavelmente ainda terão que aguardar mais alguns anos por uma maior desagregação dos setores institucionais - notadamente das empresas financeiras - nas referidas matrizes. Tal desagregação contribuiria muito para aumentar o interesse dos pesquisadores por estes dados, facilitando, em particular, a utilização destes últimos na calibragem de "blocos financeiros" de modelos macroeconômicos.

\section{REFERÊNCIAS BIBLIOGRÁFICAS}

ARAÚJO, M. S. Matriz de Fluxos de Fundos: Definição e Harmonização das Contas Financeiras. Notas Técnicas do Banco Central do Brasil, n. 4, nov. 2001.

BANCO CENTRAL. Demonstrações Financeiras. Brasília: BCB, 2009. Disponível em: <https:// www.bcb.gov.br/?id=BALANCETE\&ano=2009>. Acesso em: 31 dez. 2009.

BARBOSA-FILHO, N; RADA, C.; TAYLOR, L.; ZAMPARELLI, L. Fiscal, foreign, and private net borrowing: Widely accepted theories don't closely fit the facts.Nova York: New SchoolUniversity, 2006, mimeo.

BITTENCOURT, J. L. “A base de investidores da Dívida Pública Federal no Brasil”. In: CAPUTO SILVA, A.; OLIVEIRA C. A.; LADEIRA M. O. (Orgs.). Dívida Pública: a experiência brasileira. Brasília: Secretaria do Tesouro Nacional, 2009.

CAGETTI, M.; HOLMQUIST, E. B.; LYNN, L.; MCINTOSH, S. H.; WASSHAUSEN, D. “The integrated macroeconomic accounts of the United States". In: JORGENSON, J.; LANDEFELD, S.; SCHREYER, P. (Orgs.). Measuring economic sustainability and progress. NBER Book Series Studies in Income and Wealth. Chicago: University of Chicago Press, 2014, p. 277-321. Disponível em: <http://www.nber.org/chapters/c12834.pdf>. Acesso em 28 set. 2016. 
CAPUTO SILVA, A.; OLIVEIRA C. A.; LADEIRA M. O. (Orgs.). Dívida Pública: a experiência brasileira. Brasília: Secretaria do Tesouro Nacional, 2009.

EPSTEIN, G. A. Financialization and the World Economy. Cheltenham: Edward Elgar, 2005.

EUROPEAN COMMISSION, INTERNATIONAL MONETARY FUND, ORGANIZATION FOR ECONOMIC CO-OPERATION AND DEVELOPMENT, UNITED NATIONS, WORLD BANK. System of National Accounts 1993. New York: 1993.

EUROPEAN COMMISSION, INTERNATIONAL MONETARY FUND, ORGANIZATION FOR ECONOMIC CO-OPERATION AND DEVELOPMENT, UNITED NATIONS, WORLD BANK. System of National Accounts 2008. New York: 2009.

FED - FEDERAL RESERVE. Flow of funds in the United States: 1939-1953. Washington, DC: FED, 1993. Disponível em: <http://fraser.stlouisfed. org/docs/historical/federal\%20reserve\%20history/bog_publications/bog_flow_funds_1955.pdf>. Acesso em: 28 set. 2016.

GODLEY, W. Seven unsustainable processes: medium-term prospects and policies for the United States and the World. Special Report. Annandale-on-Hudson, N.Y.: Levy Economics Institute of Bard College, 1999.

IBGE - INSTITUTO BRASILEIRO DE GEOGRAFIA E ESTATÍSTICA. Apresentação da Nova Série do Sistema de Contas Nacionais, referência 2000 (versão para informação e comentários). Nota Metodológica $n^{\circ} 1$. Rio de Janeiro: IBGE, 2014. Disponível em: <ftp://ftp.ibge. gov.br/Contas_Nacionais/Sistema_de_Contas_Nacionais/Notas_Metodologicas/01_apresentacao.pdf>. Acesso em 25 set. 2014.

IBGE - INSTITUTO BRASILEIRO DE GEOGRAFIA E ESTATÍSTICA. Conta Financeira e Conta de Patrimônio Financeiro 2004-2009. Rio de Janeiro: IBGE, 2011.

IBGE - INSTITUTO BRASILEIRO DE GEOGRAFIA E ESTATÍSTICA. Implantação da Série do SCN - referência 2010 (versão para informação e comentários). Nota Metodológica $n^{\circ} 1$. Rio de Janeiro: IBGE, 2013a. Disponível em: <://ftp.ibge.gov.br/Contas_ Nacionais/Sistema_de_Contas_Nacionais/Notas_Metodologicas_2010/01_mudanca_de_base.pdf $>$. Acesso em: 25 set. 2014

IBGE - INSTITUTO BRASILEIRO DE GEOGRAFIA E ESTATÍSTICA. Estrutura do Sistema de Contas Nacionais. Nota Metodológica $n^{\circ}$ 2. Rio de Janeiro: IBGE, 2013b. Disponível em: $<\mathrm{ftp}$ //ftp.ibge.gov.br/Contas_Nacionais/Sistema_de_Contas_Nacionais/Notas_Metodologicas_2010/02_estrutura_scn.pdf $>$. Acesso em: 25 set. 2014.

IBGE - INSTITUTO BRASILEIRO DE GEOGRAFIA E ESTATÍSTICA. Conta Financeira e Conta de Patrimônio Financeiro (versão para informação e comentários). Nota Metodológica $n^{\circ}$ 8. Rio de Janeiro: IBGE, 2014. Disponível em: <ftp.ibge.gov.br/Contas_Nacionais/ Sistema_de_Contas_Nacionais/Notas_Metodologicas_2010/08_conta_financeira.pdf $>$. Acesso em: 25 set. 2014.

IBGE - INSTITUTO BRASILEIRO DE GEOGRAFIA E ESTATÍSTICA. Sistema de Contas Nacionais - Brasil 2010-2013 - referência 2010. Rio de Janeiro: IBGE, 2015.

LEQUILLER, F.; BLADES, D. Understanding National Accounts. Paris: OECD, 2006.

MASSARO, R. Financial accounts in historical perspective. Studi e Note di Economia, Ano 41, n. 1, p. 105-114, 2011. 
MINSKY, H. Stabilizing an unstable economy. New Haven, Londres: Yale University Press, 1986.

MINISTÉRIO DA FAZENDA, SECRETARIA DO TESOURO NACIONAL. Relatório Mensal da Dívida Pública. Brasília: MF / STN, dez. 2008.

UNITED NATIONS. A System of National Accounts. Nova York: United Nations, 1968.

WASSHAUSEN, D. Sectoral balance sheets for nonfinancial assets. In: CONFERENCE ON STRENGTHENING SECTORAL POSITION AND FLOW DATA IN THE MACROECONOMIC ACCOUNTS - IMF / OECD, Washington, DC, Feb. 28 - Mar. 2, 2011. Disponível: <http://www.bea.gov/papers/pdf/Sectoral_Balance Sheets_for_Nonfinancial_Assets.pdf>. Acesso em: 28 mar. 2011

YAMASHITA, T. A guide to the integrated macroeconomic accounts. Survey of Current Business, v. 93, n. 4, p. 12-27, abr. 2013. 